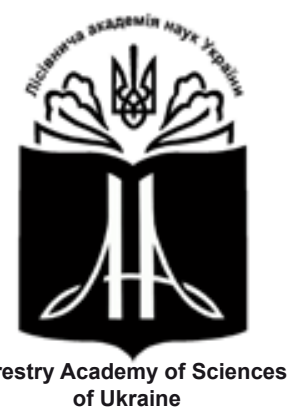

of Ukraine
Наукові праці Лісівничої академії наук України Proceedings of the Forestry Academy of Sciences of Ukraine http://fasu.nltu.edu.ua https://doi.org/10.15421/411824

Article received 2018.07.10

Article accepted 2018.10.25
ISSN 1991-606X print

ISSN 2616-5015 online

(a) $\square$ Correspondence author

Andriy Zadorozhnyy

andriy.zadorozhnyy@uzhnu.edu.ua

\title{
Динаміка залежності надземної фітомаси букових деревостанів від їхніх таксаційних показників у переважаючих типах лісорослинних умов Полонинського хребта Українських Карпат
}

\author{
Г.Г. Гриник' ${ }^{1}$ А.І. Задорожний
}

Розроблено регресійні моделі залежності основних компонентів надземної фітомаси в абсолютно сухому стані від середньої висоти, середнього діаметра та відносної повноти деревостанів бука лісового в умовах вологого сугруду та вологого груду. Для отриманих за результатами табулювання функиій значень компонентів надземної фітомаси деревостанів бука лісового в обох досліджуваних типах лісорослинних умов простежено збільшення фітомаси із зростанням значення середніх висоти та діаметра стовбура. У типі лісорослинних умов $C_{3}$ значення фітомаси деревини стовбура у досліджуваному діапазоні середніх висот зростають від 10,5-16,8 до 318-331 m·га $327 \mathrm{~m} \cdot 2 a^{-1}$. Різниця частки у значеннях изього показника зменшується із збільшенням середніх значень $і$ висоти і діаметра стовбура. Аналогічну тенденцію простежено для фітомаси кори стовбура, кори гілок та загальної надземної фітомаси букових деревостанів. Для таких компонентів, як фітомаса деревини гілок та фітомаса листя зі збільшенням значень середньої висоти та середнього діаметра деревостану встановлено збільшення частки різниці між ичими значеннями у досліджуваних типах лісорослинних умов. Вищі значення компонентів надземної фітомаси - в умовах вологого сугруду, порівняно із вологим грудом. Значення загальної надземної фітомаси збільшуються в типі лісорослинних умов $\mathrm{C}_{3}$ від 18,7-26,8 $\mathrm{m} \cdot 2 \mathrm{a}^{-1}$ за висоти $4 \mathrm{м} \mathrm{до} 415-438 \mathrm{~m} \cdot 2 \mathrm{a}^{-1}$ за

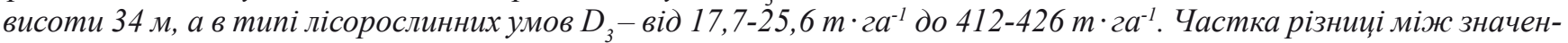
нями загальної надземної фітомаси в межах ступеня висоти зменшується зі збільшенням середнього діаметра.

Ключові слова: деревина та кора стовбура; деревина та кора гілок; середні таксаційні показники деревостану; відносна повнота; середня висота; середній діаметр; вологий сугруд; вологий груд.

Вступ. Зважаючи на динамічні процеси зміну клімату, участь лісів у яких є надзвичайно важливим чинником, дослідження їхньої біологічної продуктивності є актуальною (Shvydenko, Lakyda, \& Shchepashchenko, 2014). У цій царині можна виділити три основних компоненти, які є цікавими для дослідження: передусім - це фітомаса дерев яка, у тому числі, формує надземну фітомасу деревостану (Lakyda, 2002), мортмаса - це органічна речовина відмерлих дерев (Harmon et al., 1986; Bilous, 2015) та біологічна продукція - це органічна речовина, яка щорічно утворюється у живих деревах (Harmon, Franklin, Swanson et al., 1986, Lakyda, Bilous \& Vasylyshyn, 2010). Компонентом, який посідає фактично чільне місце у згаданому переліку, є надземна фітомаса деревостану (Lakyda, 2002), оскільки, крім того, що має найвищий ступінь залежності від лісівничо-таксаційних показників деревостану, ре-

\footnotetext{
Гриник Георгій Георгійович - член-кореспондент Лісівничої академії наук України, доктор сільськогосподарських наук, професор кафедри лісової таксації та лісовпорядкування ННІ лісового та садово-паркового господарства, старший науковий співробітник. Національний лісотехнічний університет України, вул. генерала Чупринки, 103, м. Львів, Україна, 79057. Тел. +38-096-541-39-51. E-mail: h.hrynyk@nltu.edu.ua

2 Задорожний Андрій Іванович - старший викладач кафедри лісівництва географічного факультету. Ужгородський національний університет, вул. Університетська, 14, м. Ужгород, Україна, 88000. Тел. +38-0312-64-03-54 E-mail: andriy.zadorozhnyy@uzhnu.edu.ua
} 
шта компонентів фактично є похідними від нього (Lakyda, 2001, Usoltcev \& Zalesov, 2005).

Дослідження біопродуктивності лісів загалом та надземної фітомаси деревостану зокрема повинно грунтуватися на принципах системного підходу до оцінювання ступеня впливу чи взаємодії природних чинників (Liepa, 1971, Lakyda, 2011). Зважаючи на істотну біологічну різноманітність Українських Карпат багато наукових досліджень зосереджені на оцінюванні можливості депонування лісових екосистем атмосферного вуглецю, причому аналізу піддаються практично усі фракції надземної фітомаси екосистеми (Shpakivska \& Maryskevych, 2009, Shpakivska, 2013). У нашому дослідженні, яке продовжує дослідження особливостей надземної фітомаси деревостанів бука лісового, на основі уже здійснених аналізів та узагальнень (Zadorozhnyy, 2015, Hrynyk \& Zadorozhnyy, 2018) розглянемо особливості формування структурних компонентів надземної фітомаси та здійснимо їхню формалізацію на основі регресійного аналізу з урахуванням типів лісорослинних умов. Для цього, зважаючи на досвід попередніх дослідників, використовуємо метод багатомірної математичної статистики, який найчастіше застосовують у практиці біометричних досліджень (Gillespie, 1989, Usoltcev \& Zalesov, 2005, Lakyda et al., 2013).

Об'скти та методика дослідження. Об' $\mathrm{\epsilon} к \mathrm{~m}$ дослідження - деревостани бука лісового у переважаючих типах лісорослинних умов Полонинського хребта Українських Карпат. Предмет дослідження - компоненти надземної фітомаси букових деревостанів у досліджуваних типах лісу. Mema дослідження - моделювання залежності надземної фітомаси букових деревостанів від їхніх таксаційних показників у типах лісорослинних умов (ТЛУ) $\mathrm{C}_{3}$ та $\mathrm{D}_{3}$ Полонинського хребта Українських Карпат.

Матеріали і методи. Для дослідження динаміки надземної фітомаси букових деревостанів використано дослідні дані, отримані за результатами закладання 36 тимчасових пробних площ (ТПП) 3 оцінкою компонентів фітомаси деревостанів на території Полонинського хребта Українських Карпат у межах лісового фонду державних підприємств «Міжгірське ЛГ», «Воловецьке ЛГ» та «Свалявське ЛГ» Закарпатського обласного управління лісового і мисливського господарства. Пробні площі закладено у деревостанах, які ростуть у типах лісу: волога грабова бучина (6 шт.), волога чиста бучина (8 шт.), волога ялицева бучина (4 шт.), волога чиста субучина (6 шт.), волога ялиново-ялицева субучина (5 шт.), волога грабова субучина (7 шт.); вік досліджуваних деревостанів на пробних площах - від 12 до 137 років, клас бонітету - I-II; відносна повнота - від 0,62 до 0,79. Модельні дерева вибирали за принципом репрезентативності до розподілу за ступенями товщини з урахуванням значень висоти. Для встановлення компонентів фітомаси деревостанів відібрано і досліджено 834 зразки із загалом 172 модельних дерев. Пробні площі закладено за діючими вимогами до пробних площ лісовпорядних
(SOU 02.02-37-476: 2006), а оцінювання щільності компонентів фітомаси листяних деревостанів здійснено за методикою проф. П.I. Лакиди (Lakyda, 2002, Lakyda, 2006, Lakyda, Bilous \& Vasylyshyn, 2010). Дослідні дані, отримані за результатом польових експериментальних робіт, опрацьовано в камеральних умовах $з$ використанням прикладних програм Statistica 10 та MS Excel. Для розроблення нормативів оцінки компонентів надземної фітомаси окремих дерев 3 наступним використанням отриманих результатів, для оцінювання фітомаси деревостанів використано значення щільності матеріалу в абсолютно сухому стані (Zadorozhnyy, 2015, Hrynyk \& Zadorozhnyy, 2018).

Результати та обговорення. Значення показників фітомаси розраховано на основі щільності відповідних іiі фракцій в абсолютно сухому стані та розраховано в $\left[\mathrm{T} \cdot \mathrm{ra}^{-1}\right]$. Таксаційні ознаки, використані як вхідні параметри моделі, визначено на основі кореляційного аналізу.

Отримані математичні моделі мають вигляд:

- для типу лісорослинних умов $\mathrm{C}_{3}$ :

- phm $_{\text {д.cm. }}=-38,8285+16,8147 \cdot D^{0,2987} \cdot H^{0,6345} \cdot \Pi^{0,6111}, R^{2}=0,85 ;(1)$

- phm $_{\text {K. } . \mathrm{m} .}=-4,8536+3,9300 \cdot D^{0,0601} \cdot H^{0,4696} \cdot \Pi^{0,6859}, R^{2}=0,81$;

$-p h m_{\partial .2 .}=-14,9872+9,9573 \cdot D^{0,1680} \cdot H^{0,5282} \cdot \Pi^{0,7579}, R^{2}=0,84$;

- phm $_{\text {K.2. }}=-1,3222+1,3220 \cdot D^{-0,0199} \cdot H^{0,4736} \cdot \Pi^{0,8370}, R^{2}=0,85$;

- $p h m_{l_{l}}=-2,9127+2,0755 \cdot D^{0,0934} \cdot H^{0,5728} \cdot \Pi^{0,7494}, R^{2}=0,84$,

де $p h m_{\text {д.с. }}$ - фітомаса деревини стовбурів букових деревостанів; phm к.с. - фітомаса кори стовбурів; $p h m_{\text {д.. }}$ - фітомаса гілок; $p h m_{\kappa .2 . к}-$ фітомаса кори

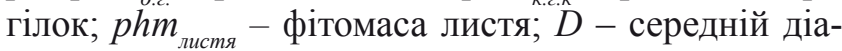
метр стовбура, см; $H$ - середня висота стовбура, м; $\Pi$ - відносна повнота;

- для типу лісорослинних умов $\mathrm{D}_{3}$ :

- $p h m_{\partial . c m .}=-38,8647+16,7358 \cdot D^{0,2991} \cdot H^{0,6338} \cdot \Pi^{0,6254}, R^{2}=0,83 ;(6)$

- phm K.cm. $=-4,8541+3,8796 \cdot D^{0,0598} \cdot H^{0,4668} \cdot \Pi^{0,6861}, R^{2}=0,84$;

- $p h m_{\text {d.2. }}=-15,5320+10,1573 \cdot D^{0,1521} \cdot H^{0,5047} \cdot \Pi^{0,6323}, R^{2}=0,88$;

- $p h m_{\text {K.2. }}=-1,3158+1,3121 \cdot D^{0,0190} \cdot H^{0,4692} \cdot \Pi^{0,8322}, R^{2}=0,85$;

- phm $m_{l .}=-2,7209+2,0001 \cdot D^{0,0935} \cdot H^{0,5735} \cdot \Pi^{0,7856}, R^{2}=0,91$.

Зважаючи на досить високі значення показника регресії для різних компонентів надземної фітомаси деревостанів (0,81-0,91), отримані рівняння можна використовувати для моделювання їхньої динаміки залежно від вибраних таксаційних показників. Результати табулювання значень компонентів надземної фітомаси деревостанів бука лісового залежно від середніх значень висоти й діаметра стовбура та відносної повноти у досліджуваних типах лісорослинних умов наведено у табл. 1-12.

Аналізуючи протабульовані за рівняннями (1) та (6) значення надземної фітомаси деревини стовбурів букових деревостанів у типах лісорослинних умов $\mathrm{C}_{3}$ та $\mathrm{D}_{3}$ (див. табл. 1 та 2 відповідно), встановлено, що у біднішому трофотопі значення досліджуваного показника є дещо вищими. Загальна тенденція для 
обох типів лісорослинних умов полягає у збільшенні стовбурової фітомаси зі збільшенням середніх значень висоти та діаметра стовбура у деревостанах. В умовах $\mathrm{C}_{3}$ значення показника змінюються від 10,5-
16,8 т $\cdot$ га $^{-1}$ за середньої висоти 4 м до 318-331 т $\cdot \mathrm{ra}^{-1}$ за середньої висоти 34 м, тоді як в умовах $\mathrm{D}_{3}$ збільшення відбувається за аналогічних значень середньої висоти - від 9,9-16,2 до 314-327 т $\cdot$ га $^{-1}$.

Фітомаса деревини стовбурів деревостанів бука лісового в ТЛУ $\mathrm{C}_{3}$ в абсолютно сухому стані (відносна повнота 0,7$), \mathbf{T} \cdot \boldsymbol{\Gamma a}^{-1}$

Таблиия 1

\begin{tabular}{cccccccccccccccccc}
\hline \multirow{2}{*}{ Діаметр, см } & \multicolumn{11}{c}{ Висота, м } \\
\cline { 2 - 6 } & 4 & 6 & 8 & 10 & 12 & 14 & 16 & 18 & 20 & 22 & 24 & 26 & 28 & 30 & 32 & 34 \\
\hline 4 & 10,5 & 24,9 & - & - & - & - & - & - & - & - & - & - & - & - & - & - \\
6 & 16,8 & 33,1 & 47,6 & - & - & - & - & - & - & - & - & - & - & - & - & - \\
8 & - & 39,6 & 55,3 & 69,6 & 83 & - & - & - & - & - & - & - & - & - & - & - \\
10 & - & 45,0 & 61,8 & 77,1 & 91 & - & - & - & - & - & - & - & - & - & - & - \\
12 & - & - & 67,4 & 83,6 & 99 & 113 & - & - & - & - & - & - & - & - & - & - \\
14 & - & - & - & 89,4 & 105 & 120 & 134 & - & - & - & - & - & - & - & - & - \\
16 & - & - & - & - & 111 & 126 & 141 & - & - & - & - & - & - & - & - & - \\
18 & - & - & - & - & 116 & 132 & 147 & 162 & - & - & - & - & - & - & - & - \\
20 & - & - & - & - & - & 138 & 153 & 168 & 183 & - & - & - & - & - & - & - \\
22 & - & - & - & - & - & - & 159 & 174 & 189 & 203 & - & - & - & - & - & - \\
24 & - & - & - & - & - & - & - & 180 & 195 & 210 & 224 & - & - & - & - & - \\
26 & - & - & - & - & - & - & - & - & - & 216 & 230 & 244 & 258 & - & - & - \\
28 & - & - & - & - & - & - & - & - & - & - & 236 & 250 & 264 & 278 & - & - \\
30 & - & - & - & - & - & - & - & - & - & - & - & 256 & 271 & 284 & 298 & - \\
32 & - & - & - & - & - & - & - & - & - & - & - & - & 277 & 291 & 304 & 318 \\
34 & - & - & - & - & - & - & - & - & - & - & - & - & - & 297 & 311 & 324 \\
36 & - & - & - & - & - & - & - & - & - & - & - & - & - & - & 317 & 331 \\
\hline
\end{tabular}

Фітомаса деревини стовбурів деревостанів бука лісового в ТЛУ $\mathrm{D}_{3}$

Таблиия 2 в абсолютно сухому стані (відносна повнота 0,7$), \mathbf{T} \cdot \Gamma \mathbf{a}^{-1}$

\begin{tabular}{ccccccccccccccccccc}
\hline \multirow{2}{*}{ Діаметр, см } & \multicolumn{11}{c}{ Висота, м } \\
\cline { 2 - 16 } & 4 & 6 & 8 & 10 & 12 & 14 & 16 & 18 & 20 & 22 & 24 & 26 & 28 & 30 & 32 & 34 \\
\hline 4 & 9,9 & 24,2 & - & - & - & - & - & - & - & - & - & - & - & - & - & - \\
6 & 16,2 & 32,4 & 46,6 & - & - & - & - & - & - & - & - & - & - & - & - & - \\
8 & - & 38,8 & 54,3 & 68,5 & 82 & - & - & - & - & - & - & - & - & - & - & - \\
10 & - & 44,1 & 60,7 & 75,9 & 90 & - & - & - & - & - & - & - & - & - & - & - \\
12 & - & - & 66,3 & 82,3 & 97 & 111 & & - & - & - & - & - & - & - & - & - \\
14 & - & - & - & 88,0 & 104 & 118 & 132 & - & - & - & - & - & - & - & - & - \\
16 & - & - & - & - & 109 & 125 & 139 & - & - & - & - & - & - & - & - & - \\
18 & - & - & - & - & 115 & 130 & 145 & 160 & - & - & - & - & - & - & - & - \\
20 & - & - & - & - & - & 136 & 151 & 166 & 180 & - & - & - & - & - & - & - \\
22 & - & - & - & - & - & - & 157 & 172 & 186 & 201 & - & - & - & - & - & - \\
24 & - & - & - & - & - & - & - & 177 & 192 & 207 & 221 & - & - & - & - & - \\
26 & - & - & - & - & - & - & - & - & - & 213 & 227 & 241 & 254 & - & - & - \\
28 & - & - & - & - & - & - & - & - & - & - & 233 & 247 & 261 & 274 & - & - \\
30 & - & - & - & - & - & - & - & - & - & - & & 253 & 267 & 281 & 294 & - \\
32 & - & - & - & - & - & - & - & - & - & - & - & - & 273 & 287 & 301 & 314 \\
34 & - & - & - & - & - & - & - & - & - & - & - & - & - & 293 & 307 & 320 \\
36 & - & - & - & - & - & - & - & - & - & - & - & - & - & - & 313 & 327 \\
\hline
\end{tabular}

Різниця у значеннях фітомаси деревини стовбурів у букових деревостанах зменшується із збільшенням середніх значень і висоти, і діаметра стовбура: найбільшу різницю встановлено за висоти 4 м - від 3,7 до 5,4\%, за висоти 6 м - 2,0-2,9\%, за висоти 8 м - 1,7-2,0\% та за подальшого збільшення середньої висоти - від 1,2 до 1,6\%. Потрібно зазначити, що щільність деревини стовбурів вищою $€$ в типі лісорослинних умов $C_{3}$ (Zadorozhnyy, 2015, Hrynyk \& Zadorozhnyy, 2018). 
Фітомаса кори стовбурів деревостанів бука лісового в ТЛУ $\mathrm{C}_{3}$ в абсолютно сухому стані (відносна повнота 0,7$), \mathrm{T}^{\cdot} \boldsymbol{\Gamma a}^{-1}$

\begin{tabular}{cccccccccccccccccc}
\hline \multirow{2}{*}{ Діаметр, см } & \multicolumn{11}{c}{ Висота, м } \\
\cline { 2 - 7 } & 4 & 6 & 8 & 10 & 12 & 14 & 16 & 18 & 20 & 22 & 24 & 26 & 28 & 30 & 32 & 34 \\
\hline 4 & 1,56 & 2,90 & - & - & - & - & - & - & - & - & - & - & - & - & - & - \\
6 & 1,72 & 3,09 & 4,24 & - & - & - & - & - & - & - & - & - & - & - & - & - \\
8 & - & 3,23 & 4,40 & 5,43 & 6,3 & - & - & - & - & - & - & - & - & - & - & - \\
10 & - & 3,34 & 4,53 & 5,56 & 6,5 & - & - & - & - & - & - & - & - & - & - & - \\
12 & - & - & 4,63 & 5,68 & 6,6 & 7,5 & - & - & - & - & - & - & - & - & - & - \\
14 & - & - & - & 5,78 & 6,7 & 7,6 & 8,4 & - & - & - & - & - & - & - & - & - \\
16 & - & - & - & - & 6,8 & 7,7 & 8,5 & - & - & - & - & - & - & - & - & - \\
18 & - & - & - & - & 6,9 & 7,8 & 8,6 & 9,4 & - & - & - & - & - & - & - & - \\
20 & - & - & - & - & - & 7,9 & 8,7 & 9,5 & 10,2 & - & - & - & - & - & - & - \\
22 & - & - & - & - & - & - & 8,8 & 9,5 & 10,3 & 11,0 & - & - & - & - & - & - \\
24 & - & - & - & - & - & - & - & 9,6 & 10,3 & 11,0 & 11,7 & - & - & - & - & - \\
26 & - & - & - & - & - & - & - & - & - & 11,1 & 11,8 & 12,4 & 13,0 & - & - & - \\
28 & - & - & - & - & - & - & - & - & - & - & 11,9 & 12,5 & 13,1 & 13,7 & - & - \\
30 & - & - & - & - & - & - & - & - & - & - & - & 12,6 & 13,2 & 13,8 & 14,4 & - \\
32 & - & - & - & - & - & - & - & - & - & - & - & - & 13,3 & 13,9 & 14,4 & 15,0 \\
34 & - & - & - & - & - & - & - & - & - & - & - & - & - & 13,9 & 14,5 & 15,1 \\
36 & - & - & - & - & - & - & - & - & - & - & - & - & - & - & 14,6 & 15,1 \\
\hline
\end{tabular}

Фітомаса кори стовбурів деревостанів бука лісового в ТЛУ $\mathrm{D}_{3}$

Таблиия 4 в абсолютно сухому стані (відносна повнота 0,7$), \mathrm{T}^{\circ} \mathrm{ra}^{-1}$

\begin{tabular}{ccccccccccccccccccc}
\hline \multirow{2}{*}{ Діаметр, см } & \multicolumn{11}{c}{ Висота, м } \\
\cline { 2 - 15 } & 4 & 6 & 8 & 10 & 12 & 14 & 16 & 18 & 20 & 22 & 24 & 26 & 28 & 30 & 32 & 34 \\
\hline 4 & 1,45 & 2,76 & - & - & - & - & - & - & - & - & - & - & - & - & - & - \\
6 & 1,60 & 2,95 & 4,07 & - & - & - & - & - & - & - & - & - & - & - & - & - \\
8 & - & 3,09 & 4,23 & 5,22 & 6,1 & - & - & - & - & - & - & - & - & - & - & - \\
10 & - & 3,19 & 4,35 & 5,36 & 6,3 & - & - & - & - & - & - & - & - & - & - & - \\
12 & - & - & 4,45 & 5,47 & 6,4 & 7,2 & & - & - & - & - & - & - & - & - & - \\
14 & - & - & - & 5,57 & 6,5 & 7,3 & 8,1 & - & - & - & - & - & - & - & - & - \\
16 & - & - & - & - & 6,6 & 7,4 & 8,2 & - & - & - & - & - & - & - & - & - \\
18 & - & - & - & - & 6,7 & 7,5 & 8,3 & 9,1 & - & - & - & - & - & - & - & - \\
20 & - & - & - & - & - & 7,6 & 8,4 & 9,2 & 9,9 & - & - & - & - & - & - & - \\
22 & - & - & - & - & - & - & 8,5 & 9,2 & 9,9 & 10,6 & - & - & - & - & - & - \\
24 & - & - & - & - & - & - & - & 9,3 & 10,0 & 10,7 & 11,3 & - & - & - & - & - \\
26 & - & - & - & - & - & - & - & - & - & 10,8 & 11,4 & 12,0 & 12,6 & - & - & - \\
28 & - & - & - & - & - & - & - & - & - & - & 11,5 & 12,1 & 12,7 & 13,3 & - & - \\
30 & - & - & - & - & - & - & - & - & - & - & - & 12,2 & 12,8 & 13,4 & 13,9 & - \\
32 & - & - & - & - & - & - & - & - & - & - & - & - & 12,8 & 13,4 & 14,0 & 14,5 \\
34 & - & - & - & - & - & - & - & - & - & - & - & - & - & 13,5 & 14,1 & 14,6 \\
36 & - & - & - & - & - & - & - & - & - & - & - & - & - & - & 14,1 & 14,7 \\
\hline
\end{tabular}

За подібних середніх значень діаметра та висоти розподіл дерев за ступенями відповідних показників у досліджуваних типах лісорослинних умов $\epsilon$ різними. Зазвичай у типі лісорослинних умов $\mathrm{C}_{3}$ спостерігається вища диференціація дерев за відносними ступенями як товщини, так і діаметра. У цьому типі лісорослинних умов зазвичай є більша кількість дерев, сконцентрованих у нижчих, порівняно із середнім значенням, ступенях відповідного показника. Для досягнення однакових 3 деревостанами в умовах $\mathrm{D}_{3}$ середніх значень висоти і діаметра, деревостани в типі лісорослинних умов $\mathrm{C}_{3}$ переважно мають дещо більшу кількість дерев, але більше диференційовані за ступенями товщини та висоти. Наслідки цієї диференціації найбільше помітні за середніх значень висоти від 4 до 12-14 м.

Результати табулювання функцій (2) та (7) залежності фітомаси кори стовбурів деревостанів бука лісового за відносної повноти 0,7 наведено в 
табл. 3 та 4 для типів лісорослинних умов $\mathrm{C}_{3}$ та $\mathrm{D}_{3}$ відповідно. Значення цього показника фактично повторює тенденцію залежності від аналогічних так- саційних показників фітомаси деревини стовбурів дерев - зі збільшенням висоти та діаметра відбувається збільшення цього показника.

Табличя 5

Фітомаса деревини гілок деревостанів бука лісового в ТЛУ $\mathrm{C}_{3}$ в абсолютно сухому стані (відносна повнота 0,7$), \mathbf{T} \cdot \boldsymbol{\Gamma a}^{-1}$

\begin{tabular}{|c|c|c|c|c|c|c|c|c|c|c|c|c|c|c|c|c|}
\hline \multirow{2}{*}{ Діаметр, см } & \multicolumn{16}{|c|}{ Висота, м } \\
\hline & 4 & 6 & 8 & 10 & 12 & 14 & 16 & 18 & 20 & 22 & 24 & 26 & 28 & 30 & 32 & 34 \\
\hline 4 & 5,0 & 9,7 & - & - & - & - & - & - & - & - & - & - & - & - & - & - \\
\hline 6 & 6,4 & 11,5 & 15,8 & - & - & - & - & - & - & - & - & - & - & - & - & - \\
\hline 8 & - & 12,8 & 17,3 & 21,4 & 25,1 & - & - & - & - & - & - & - & - & - & - & - \\
\hline 10 & - & 13,8 & 18,6 & 22,8 & 26,6 & - & - & - & - & - & - & - & - & - & - & - \\
\hline 12 & - & - & 19,6 & 23,9 & 27,9 & 31,5 & - & - & - & - & - & - & - & - & - & - \\
\hline 14 & - & - & - & 25,0 & 29,0 & 32,7 & 36,2 & - & - & - & - & - & - & - & - & - \\
\hline 16 & - & - & - & - & 30,0 & 33,8 & 37,4 & - & - & - & - & - & - & - & - & - \\
\hline 18 & - & - & - & - & 30,9 & 34,8 & 38,4 & 41,9 & - & - & - & - & - & - & - & - \\
\hline 20 & - & - & - & - & - & 35,7 & 39,4 & 42,9 & 46,2 & - & - & - & - & - & - & - \\
\hline 22 & - & - & - & - & - & - & 40,3 & 43,8 & 47,2 & 50,4 & - & - & - & - & - & - \\
\hline 24 & - & - & - & - & - & - & - & 44,7 & 48,1 & 51,3 & 54,5 & - & - & - & - & - \\
\hline 26 & - & - & - & - & - & - & - & - & - & 52,2 & 55,4 & 58,4 & 61,4 & - & - & - \\
\hline 28 & - & - & - & - & - & - & - & - & - & - & 56,3 & 59,4 & 62,3 & 65,2 & - & - \\
\hline 30 & - & - & - & - & - & - & - & - & - & - & - & 60,2 & 63,2 & 66,1 & 68,9 & - \\
\hline 32 & - & - & - & - & - & - & - & - & - & - & - & - & 64,1 & 67,0 & 69,9 & 72,6 \\
\hline 34 & - & - & - & - & - & - & - & - & - & - & - & - & - & 67,9 & 70,7 & 73,5 \\
\hline 36 & - & - & - & - & - & - & - & - & - & - & - & - & - & - & 71,6 & 74,4 \\
\hline
\end{tabular}

Фітомаса деревини гілок деревостанів бука лісового в $\mathbf{T} Л У \mathrm{D}_{3}$ в абсолютно сухому стані (відносна повнота 0,7$), \mathbf{T} \cdot \Gamma \mathbf{a}^{-1}$

\begin{tabular}{|c|c|c|c|c|c|c|c|c|c|c|c|c|c|c|c|c|}
\hline \multirow{2}{*}{ Діаметр, см } & \multicolumn{16}{|c|}{ Висота, м } \\
\hline & 4 & 6 & 8 & 10 & 12 & 14 & 16 & 18 & 20 & 22 & 24 & 26 & 28 & 30 & 32 & 34 \\
\hline 4 & 4,6 & 9,2 & - & - & - & - & - & - & - & - & - & - & - & - & - & - \\
\hline 6 & 5,9 & 10,8 & 14,9 & - & - & - & - & - & - & - & - & - & - & - & - & - \\
\hline 8 & - & 11,9 & 16,2 & 20,0 & 23,5 & - & - & - & - & - & - & - & - & - & - & - \\
\hline 10 & - & 12,9 & 17,3 & 21,3 & 24,8 & - & - & - & - & - & - & - & - & - & - & - \\
\hline 12 & - & - & 18,3 & 22,3 & 25,9 & 29,3 & - & - & - & - & - & - & - & - & - & - \\
\hline 14 & - & - & - & 23,2 & 26,9 & 30,3 & 33,5 & - & - & - & - & - & - & - & - & - \\
\hline 16 & - & - & - & - & 27,8 & 31,3 & 34,6 & - & - & - & - & - & - & - & - & - \\
\hline 18 & - & - & - & - & 28,6 & 32,1 & 35,5 & 38,6 & - & - & - & - & - & - & - & - \\
\hline 20 & - & - & - & - & - & 32,9 & 36,3 & 39,5 & 42,5 & - & - & - & - & - & - & - \\
\hline 22 & - & - & - & - & - & - & 37,0 & 40,3 & 43,3 & 46,2 & - & - & - & - & - & - \\
\hline 24 & - & - & - & - & - & - & - & 41,0 & 44,1 & 47,0 & 49,8 & - & - & - & - & - \\
\hline 26 & - & - & - & - & - & - & - & - & - & 47,8 & 50,6 & 53,4 & 56,0 & - & - & - \\
\hline 28 & - & - & - & - & - & - & - & - & - & - & 51,4 & 54,2 & 56,8 & 59,4 & - & - \\
\hline 30 & - & - & - & - & - & - & - & - & - & - & - & 54,9 & 57,6 & 60,2 & 62,7 & - \\
\hline 32 & - & - & - & - & - & - & - & - & - & - & - & - & 58,3 & 60,9 & 63,4 & 65,9 \\
\hline 34 & - & - & - & - & - & - & - & - & - & - & - & - & - & 61,6 & 64,2 & 66,6 \\
\hline 36 & - & - & - & - & - & - & - & - & - & - & - & - & - & - & 64,9 & 67,4 \\
\hline
\end{tabular}

Значення фітомаси кори стовбурів зростають від 1,6-1,7 т га $^{-1}$ за висоти 4 м до $15,0-15,1 \mathrm{~T} \cdot \mathrm{ra}^{-1}$ за висоти 34 м в типі лісорослинних умов $\mathrm{C}_{3}$ та від 1,4-1,6 т га $^{-1}$ до $14,5-14,7$ т $\cdot$ га $^{-1}$ в умовах $\mathrm{D}_{3}$. Різниця у значеннях фітомаси кори стовбурів за аналогічних значень таксаційних показників в умовах $\mathrm{C}_{3}$ перевищують аналогічні значення в ТЛУ $\mathrm{D}_{3}$ : за середньої висоти 4 м різниця становить 7,0-7,5\%, за 6-8 м-4,1-5, $\%$, за 10-14 м-3,5-3,9\%, за 16-22 м$3,3-3,4 \%$, та за 24 м і вище $-3,1-3,2 \%$.

Поясненням цього явища можуть бути гірші грунтові умови в типі лісорослинних умов $\mathrm{C}_{3}-$ в 
цьому випадку дерева бука для задоволення потреби у поживних речовинах і мікро- та макроелементах мусять мати розвиненішу кореневу систему, а також для забезпечення транспортування більшої кількості води та розчинених у ній сполук - більшу за об’ємом та щільністю кору, порівняно з умовами $\mathrm{D}_{3}$. Також потрібно зауважити, що різниця у значеннях фітомаси кори стовбурів є вищою, порівняно із різницею фітомаси деревини стовбурів.

Фітомаса кори гілок деревостанів бука лісового в ТЛУ $\mathbf{C}_{3}$

Таблицяя 7 в абсолютно сухому стані (відносна повнота 0,7$), \mathbf{T} \cdot \mathbf{r a}^{-1}$

\begin{tabular}{cccccccccccccccccc}
\hline \multirow{2}{*}{ Діаметр, см } & \multicolumn{11}{c}{ Висота, $\mathrm{11}$} \\
\cline { 2 - 6 } & 4 & 6 & 8 & 10 & 12 & 14 & 16 & 18 & 20 & 22 & 24 & 26 & 28 & 30 & 32 & 34 \\
\hline 4 & 0,62 & 1,03 & - & - & - & - & - & - & - & - & - & - & - & - & - & - \\
6 & 0,64 & 1,05 & 1,40 & - & - & - & - & - & - & - & - & - & - & - & - & - \\
8 & - & 1,07 & 1,41 & 1,72 & 1,99 & - & - & - & - & - & - & - & - & - & - & - \\
10 & - & 1,08 & 1,43 & 1,73 & 2,01 & - & - & - & - & - & - & - & - & - & - & - \\
12 & - & - & 1,44 & 1,74 & 2,02 & 2,27 & - & - & - & - & - & - & - & - & - & - \\
14 & - & - & - & 1,75 & 2,03 & 2,29 & 2,52 & - & - & - & - & - & - & - & - & - \\
16 & - & - & - & - & 2,04 & 2,29 & 2,53 & - & - & - & - & - & - & - & - & - \\
18 & - & - & - & - & 2,05 & 2,30 & 2,54 & 2,76 & - & - & - & - & - & - & - & - \\
20 & - & - & - & - & - & 2,31 & 2,55 & 2,77 & 2,98 & - & - & - & - & - & - & - \\
22 & - & - & - & - & - & - & 2,56 & 2,78 & 2,99 & 3,19 & - & - & - & - & - & - \\
24 & - & - & - & - & - & - & - & 2,78 & 2,99 & 3,19 & 3,38 & - & - & - & - & - \\
26 & - & - & - & - & - & - & - & - & - & 3,20 & 3,39 & 3,57 & 3,75 & - & - & - \\
28 & - & - & - & - & - & - & - & - & - & - & 3,40 & 3,58 & 3,76 & 3,92 & - & - \\
30 & - & - & - & - & - & - & - & - & - & - & - & 3,59 & 3,76 & 3,93 & 4,10 & - \\
32 & - & - & - & - & - & - & - & - & - & - & - & - & 3,77 & 3,94 & 4,10 & 4,26 \\
34 & - & - & - & - & - & - & - & - & - & - & - & - & - & 3,95 & 4,11 & 4,27 \\
36 & - & - & - & - & - & - & - & - & - & - & - & - & - & - & 4,11 & 4,27 \\
\hline
\end{tabular}

Фітомаса кори гілок деревостанів бука лісового в ТЛУ $\mathrm{D}_{3}$

в абсолютно сухому стані (відносна повнота 0,7 ), $\mathbf{T} \cdot \mathbf{r a}^{-1}$

\begin{tabular}{cccccccccccccccccc}
\hline \multirow{2}{*}{ Діаметр, см } & \multicolumn{11}{c}{ Висота, м } \\
\cline { 2 - 6 } & 4 & 8 & 10 & 12 & 14 & 16 & 18 & 20 & 22 & 24 & 26 & 28 & 30 & 32 & 34 \\
\hline 4 & 0,60 & 1,00 & - & - & - & - & - & - & - & - & - & - & - & - & - & - \\
6 & 0,62 & 1,02 & 1,36 & - & - & - & - & - & - & - & - & - & - & - & - & - \\
8 & - & 1,04 & 1,38 & 1,67 & 1,94 & - & - & - & - & - & - & - & - & - & - & - \\
10 & - & 1,05 & 1,39 & 1,68 & 1,95 & - & - & - & - & - & - & - & - & - & - & - \\
12 & - & - & 1,40 & 1,70 & 1,96 & 2,21 & - & - & - & - & - & - & - & - & - & - \\
14 & - & - & - & 1,70 & 1,97 & 2,22 & 2,45 & - & - & - & - & - & - & - & - & - \\
16 & - & - & - & - & 1,98 & 2,23 & 2,46 & - & - & - & - & - & - & - & - & - \\
18 & - & - & - & - & 1,99 & 2,24 & 2,47 & 2,68 & - & - & - & - & - & - & - & - \\
20 & - & - & - & - & - & 2,24 & 2,47 & 2,69 & 2,89 & - & - & - & - & - & - & - \\
22 & - & - & - & - & - & - & 2,48 & 2,70 & 2,90 & 3,09 & - & - & - & - & - & - \\
24 & - & - & - & - & - & - & - & 2,70 & 2,91 & 3,10 & 3,29 & - & - & - & - & - \\
26 & - & - & - & - & - & - & - & - & - & 3,11 & 3,29 & 3,47 & 3,64 & - & - & - \\
28 & - & - & - & - & - & - & - & - & - & - & 3,30 & 3,48 & 3,64 & 3,81 & - & - \\
30 & - & - & - & - & - & - & - & - & - & - & - & 3,48 & 3,65 & 3,81 & 3,97 & - \\
32 & - & - & - & - & - & - & - & - & - & - & - & - & 3,66 & 3,82 & 3,98 & 4,13 \\
34 & - & - & - & - & - & - & - & - & - & - & - & - & - & 3,83 & 3,98 & 4,14 \\
36 & - & - & - & - & - & - & - & - & - & - & - & - & - & - & 3,99 & 4,14 \\
\hline
\end{tabular}

Для моделювання динаміки залежності фітомаси деревини гілок у досліджуваних типах лісорослинних умов від середніх значень висоти та діаметра букових деревостанів використано регресійні рівняння (3) та (8), а протабульовані значення цих функцій наведено у табл. 5 та 6. Фітомаса деревини гілок також збільшується із середніми значеннями висоти та діаметра деревостанів у обох досліджуваних типах лісорослинних умов. У типі лісорослинних умов $\mathrm{C}_{3}$ значення цього показника зростає від 5,0-6,4 т га $^{-1}$ 
за висоти 4 м до 72,6-74,4 т· га ${ }^{-1}$ за висоти 34 м. Для деревостанів, які ростуть в умовах $\mathrm{D}_{3}$ цей показник зростає від 4,6-5,9 т· га $\mathrm{a}^{-1}$ за висоти 4 м до 65,9$67,4 \mathrm{~T} \cdot \mathrm{ra}^{-1}$ за висоти 34 м. Потрібно зазначити, що для фітомаси деревини гілок букових деревостанів характерним є збільшення різниці між аналогічними значеннями у досліджуваних типах лісорослинних умов зі збільшенням таксаційних показників: в ТЛУ $\mathrm{C}_{3}$ значення $є$ вищими і переважають аналогічні в умовах $\mathrm{D}_{3}$ від 5,8-8,0 \% у діапазоні середніх висот 4-14 м до 9,5-10,4 \% - 26-34 м. Частка різниці збільшується в межах одного степеня висоти зі збільшенням значення середнього діаметра.

Фітомаса листя деревостанів бука лісового в ТЛУ $\mathrm{C}_{3}$ в абсолютно сухому стані (відносна повнота 0,7$), \mathbf{T} \cdot \mathbf{r a}^{-1}$

\begin{tabular}{|c|c|c|c|c|c|c|c|c|c|c|c|c|c|c|c|c|}
\hline \multirow{2}{*}{ Діаметр, см } & \multicolumn{16}{|c|}{ Висота, м } \\
\hline & 4 & 6 & 8 & 10 & 12 & 14 & 16 & 18 & 20 & 22 & 24 & 26 & 28 & 30 & 32 & 34 \\
\hline 4 & 1,09 & 2,13 & - & - & - & - & - & - & - & - & - & - & - & - & - & - \\
\hline 6 & 1,24 & 2,33 & 3,27 & - & - & - & - & - & - & - & - & - & - & - & - & - \\
\hline 8 & - & 2,47 & 3,44 & 4,30 & 5,10 & - & - & - & - & - & - & - & - & - & - & - \\
\hline 10 & - & 2,58 & 3,57 & 4,45 & 5,26 & - & - & - & - & - & - & - & - & - & - & - \\
\hline 12 & - & - & 3,68 & 4,58 & 5,41 & 6,17 & - & - & - & - & - & - & - & - & - & - \\
\hline 14 & - & - & - & 4,69 & 5,53 & 6,30 & 7,04 & - & - & - & - & - & - & - & - & - \\
\hline 16 & - & - & - & - & 5,63 & 6,42 & 7,16 & - & - & - & - & - & - & - & - & - \\
\hline 18 & - & - & - & - & 5,73 & 6,52 & 7,27 & 7,98 & - & - & - & - & - & - & - & - \\
\hline 20 & - & - & - & - & - & 6,62 & 7,37 & 8,09 & 8,78 & - & - & - & - & - & - & - \\
\hline 22 & - & - & - & - & - & - & 7,47 & 8,19 & 8,88 & 9,54 & - & - & - & - & - & - \\
\hline 24 & - & - & - & - & - & - & - & 8,28 & 8,98 & 9,65 & 10,3 & - & - & - & - & - \\
\hline 26 & - & - & - & - & - & - & - & - & - & 9,74 & 10,4 & 11,0 & 11,6 & - & - & - \\
\hline 28 & - & - & - & - & - & - & - & - & - & - & 10,5 & 11,1 & 11,7 & 12,3 & - & - \\
\hline 30 & - & - & - & - & - & - & - & - & - & - & - & 11,2 & 11,8 & 12,4 & 13,0 & - \\
\hline 32 & - & - & - & - & - & - & - & - & - & - & - & - & 11,9 & 12,5 & 13,1 & 13,6 \\
\hline 34 & - & - & - & - & - & - & - & - & - & - & - & - & - & 12,6 & 13,2 & 13,7 \\
\hline 36 & - & - & - & - & - & - & - & - & - & - & - & - & - & - & 13,3 & 13,8 \\
\hline
\end{tabular}

Фітомаса листя деревостанів бука лісового в ТЛУ D в абсолютно сухому стані (відносна повнота 0,7$), \mathbf{T} \cdot \boldsymbol{\Gamma a}^{-1}$

\begin{tabular}{|c|c|c|c|c|c|c|c|c|c|c|c|c|c|c|c|c|}
\hline \multirow{2}{*}{ Діаметр, см } & \multicolumn{16}{|c|}{ Висота, м } \\
\hline & 4 & 6 & 8 & 10 & 12 & 14 & 16 & 18 & 20 & 22 & 24 & 26 & 28 & 30 & 32 & 34 \\
\hline 4 & 1,09 & 2,09 & - & - & - & - & - & - & - & - & - & - & - & - & - & - \\
\hline 6 & 1,24 & 2,27 & 3,17 & - & - & - & - & - & - & - & - & - & - & - & - & - \\
\hline 8 & - & 2,41 & 3,33 & 4,15 & 4,91 & - & - & - & - & - & - & - & - & - & - & - \\
\hline 10 & - & 2,52 & 3,46 & 4,30 & 5,07 & - & - & - & - & - & - & - & - & - & - & - \\
\hline 12 & - & - & 3,56 & 4,42 & 5,21 & 5,94 & - & - & - & - & - & - & - & - & - & - \\
\hline 14 & - & - & - & 4,52 & 5,32 & 6,07 & 6,76 & - & - & - & - & - & - & - & - & - \\
\hline 16 & - & - & - & - & 5,42 & 6,18 & 6,88 & - & - & - & - & - & - & - & - & - \\
\hline 18 & - & - & - & - & 5,51 & 6,27 & 6,99 & 7,67 & - & - & - & - & - & - & - & - \\
\hline 20 & - & - & - & - & - & 6,36 & 7,09 & 7,77 & 8,42 & - & - & - & - & - & - & - \\
\hline 22 & - & - & - & - & - & - & 7,17 & 7,87 & 8,52 & 9,16 & - & - & - & - & - & - \\
\hline 24 & - & - & - & - & - & - & - & 7,95 & 8,62 & 9,25 & 9,9 & - & - & - & - & - \\
\hline 26 & - & - & - & - & - & - & - & - & - & 9,34 & 10,0 & 10,6 & 11,1 & - & - & - \\
\hline 28 & - & - & - & - & - & - & - & - & - & - & 10,0 & 10,6 & 11,2 & 11,8 & - & - \\
\hline 30 & - & - & - & - & - & - & - & - & - & - & - & 10,7 & 11,3 & 11,9 & 12,4 & - \\
\hline 32 & - & - & - & - & - & - & - & - & - & - & - & - & 11,4 & 12,0 & 12,5 & 13,1 \\
\hline 34 & - & - & - & - & - & - & - & - & - & - & - & - & - & 12,1 & 12,6 & 13,2 \\
\hline 36 & - & - & - & - & - & - & - & - & - & - & - & - & - & - & 12,7 & 13,2 \\
\hline
\end{tabular}

Моделювання динаміки фітомаси кори гілок букових деревостанів здійснено за допомогою рівнянь (4) та (8), а результати табулювання за цим показником наведено у табл. 7 та 8. За відносної повноти 0,7 фітомаса кори гілок в типі лісорослинних умов $\mathrm{C}_{3}$ зростає від 0,62-0,64 т $\cdot \mathrm{ra}^{-1}$ за висоти 
4 м до 4,26-4,27 т га $^{-1}$ за висоти 34 м, а в умовах $\mathrm{D}_{3}$ за аналогічних значень середньої висоти - від 0,6062 т га $^{-1}$ до 4,13-4,14 т га $^{-1}$. У цьому випадку найбільшу різницю значень зафіксовано за середньої висоти 4 м і становить близько 3,2\%. Від ступеня середньої висоти від 6 до 16 м частка різниці збільшується зі збільшенням значенням середнього діа- метра, а від 18 до 34 м - $є$ фактично незмінною і не залежить від динаміки середнього діаметра стовбура. Від ступеня висоти 6 м до 16 м частка різниці зростає від 2,8 до 3,0\%, а від 18 до 34 м - від 3,0 до 3,1\%. Отже, на відміну від фітомаси деревини гілок фітомаса кори гілок у досліджуваних типах лісорослинних умов відрізняється не істотно.

Загальна надземна фітомаса деревостанів бука лісового в ТЛУ С

Табличя 11 в абсолютно сухому стані (відносна повнота 0,7$), \mathbf{T} \cdot \mathbf{r a}^{-1}$

\begin{tabular}{|c|c|c|c|c|c|c|c|c|c|c|c|c|c|c|c|c|}
\hline \multirow{2}{*}{ Діаметр, см } & \multicolumn{16}{|c|}{ Висота, м } \\
\hline & 4 & 6 & 8 & 10 & 12 & 14 & 16 & 18 & 20 & 22 & 24 & 26 & 28 & 30 & 32 & 34 \\
\hline 4 & 18,7 & 40,7 & - & - & - & - & - & - & - & - & - & - & - & - & - & - \\
\hline 6 & 26,8 & 51,1 & 72,3 & - & - & - & - & - & - & - & - & - & - & - & - & - \\
\hline 8 & - & 59,2 & 81,9 & 102,5 & 121 & - & - & - & - & - & - & - & - & - & - & - \\
\hline 10 & - & 65,9 & 89,9 & 111,6 & 132 & - & - & - & - & - & - & - & - & - & - & - \\
\hline 12 & - & - & 96,8 & 119,5 & 141 & 160 & 179 & - & - & - & - & - & - & - & - & - \\
\hline 14 & - & - & - & 126,5 & 148 & 169 & 188 & - & - & - & - & - & - & - & - & - \\
\hline 16 & - & - & - & - & 155 & 177 & 197 & - & - & - & - & - & - & - & - & - \\
\hline 18 & - & - & - & - & 162 & 184 & 204 & 224 & 243 & 261 & - & - & - & - & - & - \\
\hline 20 & - & - & - & - & - & 190 & 211 & 231 & 251 & 269 & - & - & - & - & - & - \\
\hline 22 & - & - & - & - & - & - & 218 & 239 & 258 & 277 & - & - & - & - & - & - \\
\hline 24 & - & - & - & - & - & - & - & 245 & 265 & 285 & 303 & - & - & - & - & - \\
\hline 26 & - & - & - & - & - & - & - & - & - & 292 & 311 & 329 & 347 & - & - & - \\
\hline 28 & - & - & - & - & - & - & - & - & - & - & 318 & 337 & 355 & 373 & - & - \\
\hline 30 & - & - & - & - & - & - & - & - & - & - & - & 344 & 363 & 381 & 398 & 415 \\
\hline 32 & - & - & - & - & - & - & - & - & - & - & - & - & 370 & 388 & 406 & 423 \\
\hline 34 & - & - & - & - & - & - & - & - & - & - & - & - & - & 395 & 413 & 431 \\
\hline 36 & - & - & - & - & - & - & - & - & - & - & - & - & - & - & 420 & 438 \\
\hline
\end{tabular}

Загальна надземна фітомаса деревостанів бука лісового в $T Л У D_{3}$ в абсолютно сухому стані (відносна повнота 0,7$), \mathbf{T} \cdot \mathbf{\Gamma a}^{-1}$

\begin{tabular}{|c|c|c|c|c|c|c|c|c|c|c|c|c|c|c|c|c|}
\hline \multirow{2}{*}{ Діаметр, см } & \multicolumn{16}{|c|}{ Висота, м } \\
\hline & 4 & 6 & 8 & 10 & 12 & 14 & 16 & 18 & 20 & 22 & 24 & 26 & 28 & 30 & 32 & 34 \\
\hline 4 & 17,7 & 39,3 & - & - & - & - & - & - & - & - & - & - & - & - & - & - \\
\hline 6 & 25,6 & 49,4 & 70,1 & - & - & - & - & - & - & - & - & - & - & - & - & - \\
\hline 8 & - & 57,2 & 79,5 & 99,5 & 118 & - & - & - & - & - & - & - & - & - & - & - \\
\hline 10 & - & 63,8 & 87,3 & 108,5 & 128 & - & - & - & - & - & - & - & - & - & - & - \\
\hline 12 & - & - & 94,0 & 116,2 & 137 & 156 & & - & - & - & - & - & - & - & - & - \\
\hline 14 & - & - & - & 123,0 & 144 & 164 & 183 & - & - & - & - & - & - & - & - & - \\
\hline 16 & - & - & - & - & 151 & 172 & 191 & - & - & - & - & - & - & - & - & - \\
\hline 18 & - & - & - & - & 157 & 179 & 199 & 218 & - & - & - & - & - & - & - & - \\
\hline 20 & - & - & - & - & - & 185 & 206 & 225 & 244 & - & - & - & - & - & - & - \\
\hline 22 & - & - & - & - & - & - & 212 & 232 & 251 & 270 & & - & - & - & - & - \\
\hline 24 & - & - & - & - & - & - & 218 & 238 & 258 & 277 & 295 & - & - & - & - & - \\
\hline 26 & - & - & - & - & - & - & - & - & - & 284 & 302 & 320 & 338 & - & - & - \\
\hline 28 & - & - & - & - & - & - & - & - & - & 290 & 309 & 328 & 345 & 363 & - & - \\
\hline 30 & - & - & - & - & - & - & - & - & - & - & - & 334 & 353 & 370 & 387 & - \\
\hline 32 & - & - & - & - & - & - & - & - & - & - & - & - & 359 & 377 & 395 & 412 \\
\hline 34 & - & - & - & - & - & - & - & - & - & - & - & - & - & 384 & 402 & 419 \\
\hline 36 & - & - & - & - & - & - & - & - & - & - & - & - & - & - & 409 & 426 \\
\hline
\end{tabular}

Модельовані за допомогою рівнянь (5) та (10) значення фітомаси листя деревостанів бука лісового в типах лісорослинних умов $\mathrm{C}_{3}$ та $\mathrm{D}_{3}$ відповідно наведено у табл. 9 та 10. Коефіцієнти детермінації використаних рівнянь є достатньо високі (0,840,91), що свідчить про досить високий рівень відпо- 
відності моделі емпіричним значенням досліджуваного показника. Як і для попередніх компонентів надземної фітомаси деревостанів букових деревостанів, для фітомаси листя простежено збільшення значень показника зі збільшенням значень середніх висоти та діаметра деревостанів.

Значення в типі лісорослинних умов $\mathrm{C}_{3}$ зростають від 1,09-1,24 т га $^{-1}$ за середньої висоти 4 м до $13,6-16,8 \mathrm{~T} \cdot$ га $^{-1}$ за середньої висоти 34 м та в умовах $\mathrm{D}_{3}$ за аналогічних значень висоти - від 1,09-1,24 до $13,1-13,2 \mathrm{~T} \cdot \mathrm{ra}^{-1}$. Аналізуючи різницю значень у різних типах лісорослинних умов, встановлено, що частка різниці збільшується зі збільшенням значення середнього діаметра в межах ступеня висоти, а також збільшується із збільшенням значення середньої висоти деревостану. Значення частки різниці зростає від 0,1-0,5\% за висоти 4 м до 2,3-2,7\% за висоти 6 м, далі - від 3,2-3,3\% за висоти 8 м до 3,8-3,9\% за висоти 12 м, від 3,9-4,0\% за висоти 14 м до 4,2-4,3\% за висоти 24 м та від 4,3 до 4,4\% за висоти від 26 до 34 м. Отже, можна стверджувати, що найменша відмінність між значеннями фітомаси листя букових деревостанів $\epsilon$ у молодняках. Зі збільшенням віку ця різниця збільшується, але впродовж росту та розвитку деревостанів у різних типах лісорослинних умов частка різниці змінюється не істотно.

Загальну надземну фітомасу деревостанів бука лісового у досліджуваних типах лісорослинних умов обчислено як сумарне значення іiі окремих компонентів та результати наведено у табл. 11 та 12. Значення загальної фітомаси, як і для більшості іiі компонентів, зростає зі збільшенням значень середньої висоти та діаметра стовбура в обох типах лісорослинних умов, причому вищі значення впродовж усього періоду росту характерні для деревостанів у типі лісорослинних умов $\mathrm{C}_{3}$. Загалом простежено збільшення значень цього показника в умовах $\mathrm{C}_{3}$ від $18,7-26,8 \mathrm{~T} \cdot \mathrm{ra}^{-1}$ за висоти 4 м до 415 $438 \mathrm{~T} \cdot$ га $^{-1}$ за висоти $34 \mathrm{M}$, а в умовах $\mathrm{D}_{3}$ за аналогічних значень середньої висоти - від 17,7-25,6 т $\cdot$ га $^{-1}$ до 412-426 т га ${ }^{-1}$. Частка різниці між значеннями загальної надземної фітомаси в межах ступеня висоти зменшується зі збільшенням середнього діаметра. За висоти 4 м частка різниці становить 4,7$5,7 \%$, від 6 до 8 м - 2,9-3,1\%, від 10 до 12 м - 2,8$2,9 \%$, від 14 до 28 м - 2,8\%, а від 30 до 34 м - 2,9\%. Фактично найбільша різниця у значеннях загальної фітомаси спостерігається для молодняків I групи; для молодняків II групи, середньовікових та пристиглих - спостерігається зменшення та стабілізація значень частки різниці, а для стиглих деревостанів прослідковується початкове збільшення частки різниці цього показника.

Висновки. За результатами регресійного аналізу встановлено, що найпридатнішими 3 погляду точності та практичного застосування є моделі залежностей основних компонентів надземної фітомаси букових деревостанів від значень середньої висоти, середнього діаметра та відносної повноти деревостану. Розроблені моделі залежностей адекватно описують емпіричний матеріал 3 високим рівнем апроксимації та характеризуються достатньою статистичною достовірністю. На основі рівнянь моделей розроблено комплекс таблиць оцінки досліджуваних компонентів надземної фітомаси в абсолютно сухому стані. За результатами аналізу та оцінювання розроблених таблиць встановлено, що закономірності залежності значень досліджуваних компонентів надземної фітомаси букових деревостанів у переважаючих типах лісорослинних умов від вибраних таксаційних показників деревостанів цілком піддаються логічному біолого-лісівничому тлумаченню, а їхня статистична точність дозволяє рекомендувати їх для практичного використання в Українських Карпатах.

\section{Бібліографічні посилання}

Bilous, A. M. (2015). The Structure of the Deposited Carbon in Alder Forests of Ukrainian Polissya. Scientific Bulletin of Ukrainian National Forestry University, 25(3), 31-36 (in Ukrainian).

Gillespie, A. J. (1989). Linear regression models for biomass table construction using cluster samples. $\mathrm{Ca}$ nadian Journal of Forest Research, 19 (5), 664- 673.

Harmon, N. E. et al., (1986). Ecology of Coarse Woody Debris in Temperate Ecosystems. Abvance in Ecological Research, 15, 133-302. https://doi. org/10.1016/S0065-2504(08)60121-X

Hrynyk, H. H., \& Zadorozhnyy, A. I. (2018). Some Mathematical Models of Components of AboveGround Phytomass of Beech Trees Depending on Their Assessments Indexes in the Prevailing Forest Vegetation Types of Polonynsky Range of the Ukrainian Carpathians. Scientific Bulletin of UNFU, 27(10), 1625. https://doi.org/10.15421/40271002 (in Ukrainian).

Lakyda, P. I. (2001). A dynamics of supplies of carbon is in the forests of Ukraine. Collection of scientific works: Problem of silvics and forestry, 56, 86-90 (in Russian).

Lakyda, P. I. (2002). Forest phytomass of Ukraine. Ternopil: Zbruch (in Ukrainian).

Lakyda, P. I. (2006). Live biomass of birch forests in Ukrainian Polissya. Kyiv: NNC IAE (in Ukrainian).

Lakyda, P. I. (2011). Reference materials for estimating components of above-ground live biomass of trees of main forest-forming tree species of Ukraine. Kyiv: Publishing House «EKO-inform» (in Ukrainian).

Lakyda, P. I. et al. (2013). Standards for assessment of phytomass above-ground components of the forest stands of the main forest species of Ukraine. Korsun-Shevchenkivskyi: V.M. FOP Havryshenko (in Ukrainian).

Lakyda, P. I., Bilous, A. M., \& Vasylyshyn, R. D. (2010). Aspen stands of East Polesye of Ukraine is above-ground fitomass and deposited carbon. Korsun-Shevchenkivskyi: FOP V.M. Havryshenko (in Ukrainian).

Liepa, I. Y. (1971). Systems approach and mathematical modeling in biogeocoeonology. Botanical journal, 56, 577-581 (in Russian). 
Shpakivska, I. M. (2013). Balance of carbon in the forest ecosystems of Ukrainian Carpathians. Scientific bases of maintenance of biotic variety: the Ninth scientific conference of young scientists, 3, 46-52 (in Ukrainian).

Shpakivska, I. M., \& Maryskevych, O. H. (2009). Estimation of supplies of organic carbon in the forest ecosystems of East Beskidss. Forestry and agromelioration, 115, 176-180 (in Ukrainian).

Shvydenko, A. Z., Lakyda, P. I., \& Shchepashchenko, D.H. (Ed.) (2014). Carbon, climate and landing management in Ukraine: forestsector. Korsun-Shevchenkivskyi: FOP V.M. Havryshenko (in Ukrainian).

SOU 02.02-37-476: 2006. Areas of trial forest inventory. Method of laying. Kyiv: Ministry of Agrarian Policy of Ukraine (in Ukrainian).

Usoltcev, V. A., \& Zalesov, S. V. (2005). Methods for determining the biological productivity of forest stands. Ekaterinburg: UGLTU (in Russian).

Zadorozhnyy, A. (2015). The Dynamics of Phytomass Density of Beech Tree Trunks Depending Upon Site Conditions within Polonynsky Range of the Ukrainian Carpathians. Scientific Bulletin of UNFU, 25(10), 125-134. https://doi.org/10.15421/40251019 (in Ukrainian).

\section{Динамика зависимости надземной фитомассы буковых древостоев от их таксационных показателей в преобладающих лесорастительных условиях Полонынского хребта Украинских Карпат}

\section{Г.Г. Гриник', А.И. Задорожный}

В связи с отличиями в росте и развитии в разных типах лесорастительных условий рассмотрены особенности формирования структурных компонентов надземной фитомассы и осуществлена их формализация на основе регрессионного анализа в наиболее распространенных типах лесорастительных условий.

Объект исследования - древостои бука лесного в преобладающих типах лесорастительных условий Полонынского хребта Украинских Карпат. Цель

Гриник Георгий Георгиевич - член-корреспондент Лесной академии наук Украины, профессор кафедры лесной таксации и лесоустройства ННИ лесного и садово-паркового хозяйства, доктор сельскохозяйственных наук, старший научный сотрудник. Национальный лесотехнический университет Украины, ул. Ген. Чупрынки, 103, г. Львов, Украина, 79057. Тел. +38-096541-39-51. E-mail: h.hrynyk@nltu.edu.ua; ORCID: https://orcid. org/0000 - 0001-7417-5047, ResearcherID: Q-8126-2017

Задорожный Андрей Иванович - старший преподаватель кафедры лесоводства Географического факультета. Ужгородский национальный университет, ул. Университетская, 14, г. Ужгород, Украина, 88000. Тел. +38-0312-64-03-54 E-mail: andriy.zadorozhnyy@uzhnu.edu.ua; ORCID: https://orcid.org/ 0000-0002-0664-5462 исследования - моделирование зависимости надземной фитомассы буковых древостоев от их таксационных показателей.

Для исследования динамики надземной фитомассы буковых древостоев использованы опытные данные 36 временных пробных площадей с оценкой компонентов фитомассы древостоев. Пробные площади заложены по действующим требованиям, а оценивание плотности компонентов фитомассы лиственных древостоев осуществлено по методике проф. П.И. Лакиды. Использовано значение плотности материала в абсолютно сухом состоянии.

Общая тенденция для обоих типов лесорастительных условий заключается в увеличении ствольной фитомассы с увеличением средних значений высоты и диаметра ствола. В типе лесорастительных условий $\mathrm{C}_{3}$ значения показателя изменяются от 10,5-16,8 т $\cdot$ га $^{-1}$ до 318-331 т $\cdot \mathrm{a}^{-1}$, а в условиях $\mathrm{D}_{3}$ увеличение происходит при аналогичных значениях средней высоты от 9,9-16,2 т га $^{-1}$ до 314-327 т га $^{-1}$. Разница в значениях фитомассы древесины стволов уменьшается с увеличением средних значений высоты и диаметра ствола : от 3,7-5,4\% до 1,2-1,6 \%. Значения фитомассы коры стволов растут от 1,6$1,7 \mathrm{~T} \cdot \mathrm{ra}^{-1}$ до $15,0-15,1 \mathrm{~T} \cdot \mathrm{ra}^{-1}$ в типе лесорастительных условий $\mathrm{C}_{3}$ и от 1,4-1,6 т $\cdot \mathrm{ra}^{-1}$ до $14,5-14,7 \mathrm{~T} \cdot \mathrm{ra}^{-1}$ в условиях $\mathrm{D}_{3}$. Для фитомассы древесины веток буковых древостоев характерным является увеличение разницы с увеличением таксационных показателей: в условиях $\mathrm{C}_{3}$ значения выше и преобладают аналогичные в условиях $\mathrm{D}_{3}$. При относительной полноте 0,7 фитомасса коры веток в типе лесорастительных условий $\mathrm{C}_{3}$ возрастает от 0,62-0,64 т $\cdot \mathrm{ra}^{-1}$ до 4,26-4,27 т га $^{-1}$, а в условиях $\mathrm{D}_{3}$ при аналогичных значениях средней высоты - от 0,60-62 т·га ${ }^{-1}$ до 4,13-4, 14 т $\cdot$ га $^{-1}$. В отличие от фитомассы древесины веток, фитомасса коры веток в исследуемых типах лесорастительных условий отличается не существенно. Значения фитомассы листьев в условиях $\mathrm{C}_{3}$ растут от $1,09-1,24 \mathrm{~T} \cdot \mathrm{ra}^{-1}$ до $13,6-16,8 \mathrm{~T} \cdot \mathrm{ra}^{-1}$ и в условиях $\mathrm{D}_{3}$ - от 1,09-1,24 т га $^{-1}$ до $13,1-13,2 \mathrm{~T} \cdot \mathrm{ra}^{-1}$. Наименьшее отличие между значениями фитомассы листьев буковых древостоев наблюдается в молодняках. Прослеживается увеличение значений общей надземной фитомассы в типе лесорастительных условий $\mathrm{C}_{3}$ от $18,7-26,8 \mathrm{~T} \cdot \mathrm{ra}^{-1}$ до 415-438 т га $^{-1}$, а в условиях $\mathrm{D}_{3}$ - от $17,7-25,6 \mathrm{~T} \cdot \mathrm{ra}^{-1}$ до 412-426 т $\cdot \mathrm{ra}^{-1}$. Часть разницы между значениями общей надземной фитомассы в пределах степени высоты уменьшается с увеличением среднего диаметра.

Разработанные модели зависимостей адекватно описывают эмпирический материал с высоким уровнем аппроксимации и характеризуются достаточной статистической достоверностью. На основе уравнений моделей разработан комплекс таблиц оценки исследуемых компонентов надземной фитомассы в абсолютно сухом состоянии.

Ключевые слова: древесина и кора ствола; древесина и кора веток; средние таксационные показатели древостоя; относительная полнота; средняя высота; средний диаметр; влажный сугруд; влажный груд. 


\section{The dynamics of beech forests stands above-ground phytomass depending on their assessments indexes in the prevailing site types of Polonynsky Range of the Ukrainian Carpathians}

\section{H. Hrynyk ${ }^{1}$, A. Zadorozhnyy ${ }^{2}$}

In connection with differences in a height and development in the different site types the features of structural components forming of above-ground phytomass in the most prevailing site types are considered and their formalization is carried out on the basis of regressive analysis.

Object of the study - beech forests stands in the prevailing site types of Polonynsky Range of the Ukrainian Carpathians. The research aim is to design dependence of above-ground phytomass of beech forests stands from their assessments indexes.

The authors used research data obtained in the result of setting 36 temporary trial plots on the territory of Polonynsky range of the Ukrainian Carpathians in order to study the dynamics of above-ground components of above-ground phytomass of beech forets stands. Trial areas are stopped up on operating requirements, and the evaluation of closeness of components of above-ground phytomass of broadleaved forest stand is studied ed followed on methodology of Prof. P.I. Lakyda. To assess beech stands phytomass it is used the value of material density in the absolutely dry state.

A general tendency for studied site types consists in the increase of tree trunk phytomass with the increase

Heorhiy Hrynyk - Corresponding Member the Forestry Academy of Sciences of Ukraine, Doctor of Agricultural Sciences, Professor of Forest Assessments and Forest Management Department Ukrainian National Forestry University, Gen. Chuprynka st., 103, Lviv, 79057, Ukraine. Tel.: +38-096-541-39-51. E-mail: h.hrynyk@nltu.edu.ua; ORCID: https://orcid.org/0000-0001-7417-5047, Researcher ID: Q-8126-2017

Andriy Zadorozhnyy - Senior Teacher of the Forestry Department of Geographical Faculty. Uzhhorod National University, University st., 14, Uzhhorod, 88000, Ukraine. Tel. +38-066762-03-47 E-mail: andriy.zadorozhnyy@uzhnu.edu.ua; ORCID: https://orcid.org/0000-0002-0664-5462 of mean values of trunk height and trunk diameter . In the moist mixed broadleaved forest $\left(\mathrm{C}_{3}\right)$ conditions the values of index change from $10.5-16.8 \mathrm{t} \cdot \mathrm{he}^{-1}$ to $318-331 \mathrm{t} \cdot \mathrm{he}^{-1}$, and in moist broadleaved forest $\left(\mathrm{D}_{3}\right)$ conditions an increase takes place at the analogical values of middle high of from 9.9-16.2 $t \cdot \mathrm{he}^{-1}$ to 314 $327 \mathrm{t} \cdot \mathrm{he}^{-1}$. A difference in the values of wood trunk phytomass to diminishes with the increase of mean values of trunk height and trunk diameter: from 3.7$5.4 \%$ to $1.2-1.6 \%$. The values of trunk bark phytomass grow from 1.6-1.7 $\mathrm{t} \cdot \mathrm{he}^{-1}$ to $15.0-15.1 \mathrm{t} \cdot \mathrm{he}^{-1}$ in $\mathrm{C}_{3}$ conditions, and from 1.4-1.6 $\mathrm{t} \cdot \mathrm{he}^{-1}$ to $14.5-14.7 \mathrm{t} \cdot \mathrm{he}^{-1}$ in $\mathrm{D}_{3}$ conditions. For wood branches phytomass characteristic is an increase of difference with the increase of assessments indexes: in $\mathrm{C}_{3}$ conditions of value are higher and prevail analogical idexes in $\mathrm{D}_{3}$ conditions. At relative stocking of 0.7 a bark branches phytomass in $\mathrm{C}_{3}$ conditions grows from 0.62-0.64 $\mathrm{t} \cdot \mathrm{he}^{-1}$ to $4.26-4,27 \mathrm{t} \cdot \mathrm{he}^{-1}$, and in $\mathrm{D}_{3}$ conditions at the analogical values of middle high - from 0.60-62 to 4.13-4.14 $\mathrm{t} \cdot \mathrm{he}^{-1}$. Unlike wood branches phytomass of bark branches phytomass in the investigated site types are differs not substantially. The values of leaves phytomass in $\mathrm{C}_{3}$ conditions grow from 1.09-1.24 $\mathrm{t} \cdot \mathrm{he}^{-1}$ to $13.6-16.8 \mathrm{t} \cdot \mathrm{he}^{-1}$ and in $\mathrm{D}_{3}$ conditions - from 1.091.24 to $13.1-13.2 \mathrm{t} \cdot \mathrm{he}^{-1}$. The least difference between the values of leaves phytomass of beech forests stands is observed in sapling stands. The increase of values of general above-ground phytomass is traced in $\mathrm{C}_{3}$ conditions from 18.7-26.8 $\mathrm{t} \cdot \mathrm{he}^{-1}$ to $415-438 \mathrm{t} \cdot \mathrm{he}^{-1}$, and in $\mathrm{D}_{3}$ conditions - from 17.7-25.6 $\mathrm{t} \cdot \mathrm{he}^{-1}$ to 412 $426 \mathrm{t} \cdot \mathrm{he}^{-1}$. The part of difference between the values of general above-ground phytomass is in limits degrees of height trunk diminishes with the increase of middle trunk diameter.

The worked out models of dependences adequately describe empiric material with the high level of approximation and characterized by sufficient statistical authenticity. On the basis of models equalizations the complex of tables of the investigated components of above-ground phytomass estimation it is worked out in absolutely dry state.

Key words: trunk wood and bark; branches of wood and bark; middle assessments indexes of forests stand; relative stocking; middle high; middle diameter; moist mixed broadleaved forest; moist broadleaved forest. 